\title{
Effects of condensed tannins prepared from leaves of fodder plants on digestive enzymes in vitro and in the intestine of rats
}

\author{
BY T. HORIGOME, R. KUMAR* AND K. OKAMOTO \\ College of Agriculture, Okayama University, Tsushima, Okayama 700, Japan
}

(Received 10 December 1987 - Accepted 18 April 1988)

\begin{abstract}
1. Of the nineteen plants screened, six were found to contain large quantities of condensed tannins. Black locust (Robinia pseudo-Acacia), bush clover (Lespedeza bicolor), wistaria (Wistaria floribunda) and Japanese knotgrass (Reynoutria japonica) were used for the present experiment. Tannins of the investigated plants were fractionated into three or four molecular forms, according to the degree of polymerization, by chromatography on a column of Sephadex LH-20.

2. The protein-precipitating capacity of the fractionated tannins increased with the increase in degree of polymerization. The inhibitory effect of tannins on trypsin $(E C 3.4 .21 .4), \alpha$-amylase $(E C 3.2 .1 .1)$ and lipase $(E C 3.1 .1 .3)$ activities in vitro also increased with the increase in degree of polymerization. The digestion of tannin-bovine serum albumin complex by trypsin was related to the degree of polymerization of tannins complexed

3. Inclusion of black locust tannins in the diet $(10 \mathrm{~g} / \mathrm{kg})$ depressed the activities of trypsin and $\alpha$-amylase in the upper, middle and lower parts of the intestine of the rats, but the lipase activity was increased in the middle part and remained unaffected in the upper and lower parts. It is presumed that the tannins have little affinity for lipase.

4. Digestion trials, when the microflora level of the alimentary canal of rats was reduced by dietary antibiotic treatment, revealed that the inclusion of tannins in the diet $(20 \mathrm{~g} / \mathrm{kg})$ depressed the digestibilities of proximate constituents, except crude fat, and increased faecal bile acid excretion.
\end{abstract}

It has been shown by many researchers (Chang \& Fuller, 1964; Maxson et al. 1973; Rostagno et al. 1973; Marquardt et al. 1977; Ford \& Hewitt, 1979) that tannins have adverse effects on the growth of chicks and rats. Barry (1985) reported also that the liveweight gain and voluntary intake were low for sheep grazing high-tannin forage. Tannins are classified into hydrolysable and condensed types and the inhibitory effect on trypsin activity is more marked with condensed tannins than with hydrolysable tannins (Tamir \& Alumot, 1969). It is also suggested that the principal tannins found in forage leaves are of the proanthocyanidin type formed by the polymerization of flavan-3,4-diols either alone or in combination with other flavonoids such as catechins (McLleod, 1974; Jones et al. 1976).

The present work was undertaken to isolate tannins from the leaves of black locust (Robinia pseudo-Acacia), bush clover (Lespedeza bicolor), wistaria (Wistaria floribunda) and Japanese knotgrass (Reynoutria japonica) which were found to have proanthocyanidin-type tannins in a survey of tannin-containing plants, and to investigate the effect of isolated tannins on trypsin (EC 3.4.21.4), $\alpha$-amylase (EC 3.2.1.1) and lipase (EC 3.1.1.3) in vitro and in the intestine of rats.

\section{EXPERIMENTAL}

Survey of the plants containing condensed tannins

Anthocyanidin-formation and protein-precipitation tests were used for the survey of condensed tannin-containing plants. The plants listed in Table 1 (p. 279) were examined by

\footnotetext{
* Present address: Division of Nutrition and Forage Science, Central Sheep and Wool Research Institute, Avikanagar, Raj 304501, India.
} 
both tests. The leaves of each plant were dried in a current of hot air $\left(60^{\circ}\right)$, pulverized using a porcelain mortar and pestle and submitted to the tests. For the anthocyanidin-formation test, a sample was extracted with diethyl ether to remove chlorophyll and refluxed in concentrated hydrochloric acid- $n$-butanol $(5: 95, \mathrm{v} / \mathrm{v})$. The reaction mixture turned pinkish within a few minutes in the presence of proanthocyanidin-type tannins. For the proteinprecipitation test, a tsample was extracted with acetone-water $(70: 30, \mathrm{v} / \mathrm{v})$ and after removal of the acetone the extract was added to bovine serum albumin (BSA; A4378; Sigma Chemical Co., St Louis, MO.) solution ( $10 \mathrm{~g} / 1$, including $100 \mathrm{~g}$ sodium chloride). Coagulation of albumin was caused by the addition of a few drops of the extract containing condensed tannins. When the sample was positive to both the tests, the sample was judged to have the tannins of proanthocyanidin type.

\section{Isolation and fractionation of tannins}

The leaves of black locust, bush clover, wistaria and Japanese knotgrass were collected in June 1985 and 1986. The procedure for isolation and fractionation of tannins was carried out as described in the previous paper (Kumar \& Horigome, 1986) and is summarized as follows. The tannins were extracted from $500 \mathrm{~g}$ fresh leaves with 1.5 litres acetone-water $(70: 30, \mathrm{v} / \mathrm{v})$ containing ascrobic acid $(2 \mathrm{~g} / \mathrm{l})$ and the residue re-extracted. Combined extracts were saturated with $\mathrm{NaCl}$ to salt out the acetone phase. The acetone was removed under vacuum and the resulting aqueous solution centrifuged at $12000 \mathrm{~g}$ to be clarified. The clarified solution was extracted three times with diethyl ether and was dialyzed overnight in a cellulose tube against water. To the dialyzed solution was added an equal volume of methanol. The methanolic solution was applied to a column of Sephadex LH-20 $(26 \times 100 \mathrm{~mm})$ equilibrated with methanol-water $(50: 50, \mathrm{v} / \mathrm{v})$. The absorbed tannins were washed with $800 \mathrm{ml}$ of the same solvent and were eluted with acetone-water $(70: 30, \mathrm{v} / \mathrm{v})$. The acetone was removed under vacuum and water was removed by freeze-drying to yield light, tan, fluffy solids. The solids from black locust leaves were used as crude tannin mixture for rat experiments.

For fractionation, the tannin mixture $(0.5-0.7 \mathrm{~g})$ in $5.0 \mathrm{ml}$ acetone-water $(70: 30, \mathrm{v} / \mathrm{v})$ was submitted to a column of Sephadex LH-20 $(260 \times 300 \mathrm{~mm})$ equilibrated with acetone-water $(70: 30, \mathrm{v} / \mathrm{v})$. The column was eluted at a flow-rate of $45 \mathrm{ml} / \mathrm{h}$ with the same solvent and $3.5 \mathrm{ml}$ fractions were collected. The fractions were grouped into three or four pooled fractions by monitoring the absorbance at $350 \mathrm{~nm}$. After removal of the acetone, pooled fractions were lyophilized to yield bright tan, fluffy solids that were used for in vitro experiments with regard to the inhibitory effect of fractionated tannins on digestive enzymes. The yield of fractionated tannins was from 30 to $150 \mathrm{mg}$.

\section{In vitro action of fractionated tannins on digestive enzymes}

Trypsin, $\alpha$-amylase and lipase were chosen as representative enzymes. The enzyme preparations used were bovine pancreatic trypsin (type I, $10000 \mathrm{BAEE}$ units/mg protein; Sigma), human saliva $\alpha$-amylase (type XIII-A, 400-600 units/mg protein; Sigma) and porcine pancreatic lipase (type VI-S, 20000-50000 units/mg protein; Sigma). The solutions of various fractionated tannins were incubated for $30 \mathrm{~min}$ at $25-30^{\circ}$ with an enzyme at a tannin:enzyme value of $1: 1(\mathrm{w} / \mathrm{w})$ before the addition of substrates. Trypsin activity was determined using $N$-benzoyl-DL-arginine- $p$-nitroaniline (Sigma) as substrate in Tris buffer, $\mathrm{pH} 8 \cdot 2$, by the method of Erlanger et al. (1961). $\alpha$-Amylase activity was assayed using amylopectin (from potato; Sigma) in phosphate- $\mathrm{NaCl}$ buffer, $\mathrm{pH} 6.9$, by the method of Bernfeld (1955). Lipase activity was estimated using 2-naphthyl laurate (Sigma) as substrate in veronal- $\mathrm{HCl}$ buffer, $\mathrm{pH} \mathrm{7.4,} \mathrm{by} \mathrm{the} \mathrm{method} \mathrm{of} \mathrm{Seligman} \mathrm{\&} \mathrm{Nachlas} \mathrm{(1963).} \mathrm{The}$ 
percentage inhibition was determined by comparing the reduction in activity on the addition of tannins with the activity of the given enzyme in the absence of tannins.

The enzymic hydrolysis of the protein-tannin complex was also examined. A mixture of $1 \mathrm{ml}$ tannin solution $(5 \mathrm{mg} / \mathrm{ml}), 1 \mathrm{ml}$ BSA solution $(20 \mathrm{mg} / \mathrm{ml})$ and $3 \mathrm{ml} 0.067 \mathrm{M}$-phosphate buffer (pH 7.8) was incubated at $37^{\circ}$. After $30 \mathrm{~min}, 0.5 \mathrm{ml}$ trypsin solution $(0.5 \mathrm{mg} / \mathrm{ml}$ ) was added to the mixture and hydrolysis allowed to proceed at $37^{\circ}$ for $3 \mathrm{~h}$. The reaction was stopped by addition of $2 \mathrm{ml}$ trichloroacetic acid solution $(30: 70, \mathrm{w} / \mathrm{w})$ and the mixture centrifuged. The precipitate was analysed by the semi-microKjeldahl method and in vitro digestibilities of albumin were calculated on the basis of 1.0 for that in the absence of any tannin. D-Catechin (Sigma) was used for these experiments as a representative monomer of tannin.

Influence of tannin administration on the digestive enzymes in the intestine of rats Six Wistar male rats weighing approximately $100 \mathrm{~g}$, that had been previously accustomed to eat more than $8 \mathrm{~g}$ diet during $2 \mathrm{~h}$, were allocated to two diets, a basal diet and a test diet containing tannins. Rats were given one of these diets for the experimental period of 4 or $5 \mathrm{~d}$ and were killed with diethyl ether at the end of the experimental period $2 \mathrm{~h}$ after the diets were offered. Intestines were removed and divided in three equal segments: upper, middle and lower. The intestinal contents of each segment were collected, macerated and diluted with physiological saline $(9 \mathrm{~g} \mathrm{NaCl} / \mathrm{l})$ in a $50 \mathrm{ml}$ volumetric flask. After the centrifugation of the diluted suspension, the supernatant fraction was used for the determination of trypsin, $\alpha$-amylase and lipase activities. The enzyme activities were assayed by the methods previously described. One unit of activity was expressed in terms of $1 \mu \mathrm{mol} p$-nitroaniline, maltose or 2 -naphthol liberated by the respective enzymes. Lipase activity was defined as the difference in activity between samples in the presence and absence of taurocholic acid. The composition of the basal diet $(\mathrm{g} / \mathrm{kg})$ was: sucrose 100 , casein 100 , maize oil 100, mineral mixture (Phillips \& Hart, 1935) 40, cellulose powder 30, vitamin mixture (Harper, 1959) 10, $\alpha$-starch 620. Crude tannin mixture from black locust leaves was incorporated at the expense of $\alpha$-starch into the test diet to provide $10 \mathrm{~g} / \mathrm{kg}$. Rats were housed individually at $23 \pm 2^{\circ}$ with a $12 \mathrm{~h}$ light $-12 \mathrm{~h}$ dark cycle.

\section{Digestion experiments with rats}

Four Wistar male rats weighing approximately $85 \mathrm{~g}$ were kept individually in metabolism cages for three consecutive periods, each consisting of a preliminary period of $\mathbf{3} \mathrm{d}$ and a collection period of $4 \mathrm{~d}$. In period 1 rats were offered the basal diet described previously without any supplement, in period 2 the basal diet supplemented with antibiotics and in period 3 the test diet containing tannins $(20 \mathrm{~g} / \mathrm{kg})$ in addition to antibiotics. Antibiotics (Bacitracin-Neomycin sulphate; Sigma; 2:1, w/w) were added at a level of $7 \mathrm{~g} / \mathrm{kg}$ to the diets in periods 2 and 3 in order to reduce the microflora level in the alimentary canal (Eggum et al. 1979). Faeces were collected quantitatively, lyophylized, weighed and pulverized for analyses.

\section{Chemical procedure}

The degree of polymerization of fractionated tannins was determined by the vanillin assay in glacial acetic acid (Butler et al. 1982). D-Catechin (C1251; Sigma; containing 2.5 water/ $\mathrm{mol}$ ) was used as standard for the calculation of degree of polymerization. The degree of polymerization of fractionated tannins was obtained as the ratio, absorbance of catechin:tannins, both determinations being made on equal weights of material. The protein-precipitating capacity of tannins was assayed as follows. The mixture of $1 \mathrm{ml}$ tannin solution $(5 \mathrm{mg} / \mathrm{ml}), 1 \mathrm{ml} \mathrm{BSA}$ solution $(20 \mathrm{mg} / \mathrm{ml})$ and $3 \mathrm{ml} 0.067 \mathrm{M}$-phosphate 
buffer (pH 7.8) was allowed to stand for $30 \mathrm{~min}$ and centrifuged at $12000 \mathrm{~g}$ for $20 \mathrm{~min}$. The precipitated albumin in the supernatant fraction was determined by the semi-microKjeldahl method. Protein-precipitating capacity was expressed as $\mathrm{mg}$ precipitated albumin $/ \mathrm{mg}$ original albumin. The anthocyanidins produced by acid treatment of tannins were estimated by paper chromatography (Kumar \& Horigome, 1986). Bile acids in the faeces were estimated by the method of Kalek et al. (1984) with some modifications as follows. The powdered faecal sample $(200 \mathrm{mg})$ was refluxed in $10 \mathrm{ml}$ alkaline methanol (methanol-10 M-sodium hydroxide, $3: 1 \mathrm{v} / \mathrm{v}$ ) for $2 \mathrm{~h}$ at $80^{\circ}$. The reaction mixture was diluted with $10 \mathrm{ml}$ saline solution, extracted twice with light petroleum (b.p. $30-70^{\circ}$ ) and acidified ( $\mathrm{pH} \mathrm{1)}$ with $\mathrm{HCl}$. The methanol was removed under vacuum and the bile acids were extracted with diethyl ether. The diethyl ether was taken to dryness and the residue was dissolved in $5 \mathrm{ml}$ methanol. An adequate amount $(0.2 \mathrm{ml})$ of the methanol solution was submitted to the enzymic determination of 3- $\alpha$-hydroxy bile acids with a commercial kit (Kyokuto Seiyaku Kogyo Co., Tokyo). The acid-detergent fibre (ADF) was determined by the method of Goering \& Van Soest (1970). The moisture, crude ash, nitrogen and crude fat contents of feeds and faeces were analysed according to conventional methods. A value for $\mathrm{N}$-free extract (NFE) was obtained by adding together the five previous percentage values and subtracting the total from 100 .

\section{Statistical analysis}

The significance of the correlation coefficient between the degree of polymerization of tannins and, respectively, the protein-precipitating capacity and in vitro action on the enzymes of tannins was tested by Student's $t$ test. The results obtained in the rat experiments are presented as means and standard deviations. The statistical significances of differences between the means were evaluated by analysis of variance.

\section{RESULTS}

\section{Plants containing condensed tannins}

Nineteen plants listed in Table 1 were subjected to the tests for condensed tannins. The leaves of persimmon (Diospyros kaki), black locust, bush clover, wistaria, stylo (Stylosanthes guianensis) and Japanese knotgrass were strongly positive to both the anthocyanidinformation and the protein-precipitation tests. Strawberry (Fragaria grandiflora) was also positive but not strongly to both tests. Water hyacinth (Eichhornia crassipes) was positive to the anthocyanidin-formation test but negative to the protein-precipitation test. Black locust, bush clover, wistaria and Japanese knotgrass were chosen for the present experiments since they are plentiful in this part of the country.

\section{Properties of fractionated tannins}

Tannins from each plant were fractionated by gel filtration on Sephadex LH-20, using acetone-water $(70: 30, \mathrm{v} / \mathrm{v})$ as eluent, into three fractions, but tannins from black locust separated into four fractions. Investigation of the degree of polymerization showed that tannins from every plant were separated by size during gel filtration, that is, the fractions, for the lower elution volume had a higher degree of polymerization and the fractions eluted much later had a lower degree of polymerization. The degree of polymerization and protein-precipitating capacity of fractionated tannins are shown in Fig. 1. The relation between the degree of polymerization and protein-precipitating capacity of tannins was statistically significant $(r 0.855, P<0.01)$.

Paper chromatography of anthocyanidins formed when fractionated tannins were 
Table 1. Plants examined for condensed tannins

\begin{tabular}{|c|c|c|}
\hline & $\begin{array}{l}\text { Anthocyanidin- } \\
\text { formation test }\end{array}$ & $\begin{array}{l}\text { Protein- } \\
\text { precipitation } \\
\text { test }\end{array}$ \\
\hline $\begin{array}{l}\text { Persimmon } \\
\text { (Diospyros kaki Thunb.) }\end{array}$ & ++ & ++ \\
\hline $\begin{array}{l}\text { Black locust } \\
\text { (Robinia pseudo-Acacia L.) }\end{array}$ & ++ & ++ \\
\hline $\begin{array}{l}\text { Lucerne } \\
\text { (Medicago sativa } \mathrm{L} \text {.) }\end{array}$ & - & - \\
\hline $\begin{array}{l}\text { Bush clover } \\
\text { (Lespedeza bicolor Turcz. } \\
\text { var. japonica Nakai) }\end{array}$ & ++ & ++ \\
\hline $\begin{array}{l}\text { Red clover } \\
\text { (Trifolium pratense } \mathrm{L} . \text { ) }\end{array}$ & - & - \\
\hline $\begin{array}{l}\text { White clover } \\
\text { (Trifolium repens } \mathrm{L} \text {.) }\end{array}$ & - & - \\
\hline $\begin{array}{l}\text { Wistaria } \\
\text { (Wistaria floribunda DC) }\end{array}$ & ++ & ++ \\
\hline $\begin{array}{l}\text { Kudzu-Vine } \\
\text { (Pueraria lobata } \text { Ohwi) }\end{array}$ & - & - \\
\hline $\begin{array}{l}\text { Stylo } \\
\text { (Stylosanthes guianensis } \\
\text { cv. Schofield) }\end{array}$ & ++ & ++ \\
\hline $\begin{array}{l}\text { Siratro } \\
\text { (Macroptilium atropurpureum } \\
\text { cv. Siratro) }\end{array}$ & - & - \\
\hline $\begin{array}{l}\text { Mugwort } \\
\text { (Artemisia vulgaris. } \mathrm{L} . \\
\text { var. indica Maxim.) }\end{array}$ & - & - \\
\hline $\begin{array}{l}\text { Sunflower } \\
\text { (Helianthus annuus L.) }\end{array}$ & - & - \\
\hline $\begin{array}{l}\text { Japanese knotgrass } \\
\text { (Reynoutria japonica } \text { Houtt.) }\end{array}$ & ++ & ++ \\
\hline $\begin{array}{l}\text { Plantain } \\
\text { (Plantago asiatica } \text { L.) }\end{array}$ & - & - \\
\hline $\begin{array}{l}\text { Asitaba } \\
\text { (Angelica Keiskei Koidz.) }\end{array}$ & - & - \\
\hline $\begin{array}{l}\text { Italian ryegrass } \\
\text { (Lolium multiflorum Lam.) }\end{array}$ & - & - \\
\hline $\begin{array}{l}\text { Napier grass } \\
\text { (Pennisetum purpureum Schum.) }\end{array}$ & - & - \\
\hline $\begin{array}{l}\text { Cultivated strawberry } \\
\text { (Fragaria grandifora } \text { Ehrh.) }\end{array}$ & + & + \\
\hline $\begin{array}{l}\text { Water hyacinth } \\
\text { (Eichhornia crassipes Solms-Laub.) }\end{array}$ & + & - \\
\hline
\end{tabular}

- , Negative; + , positive; ++ , strongly positive to the test.

treated separately with $\mathrm{HCl}$-butanol revealed the presence of delphinidin and cyanidin in black locust, bush clover and wistaria. In the case of Japanese knotgrass, however, the band or spot of delphinidin on the paper chromatogram was faint or not appreciable.

In vitro action of fractionated tannins on digestive enzymes

Figs. 2, 3 and 4 show the relation between the digestive enzyme inhibitor activity and the degree of polymerization for all fractionated tannins from four plants. The inhibitor 


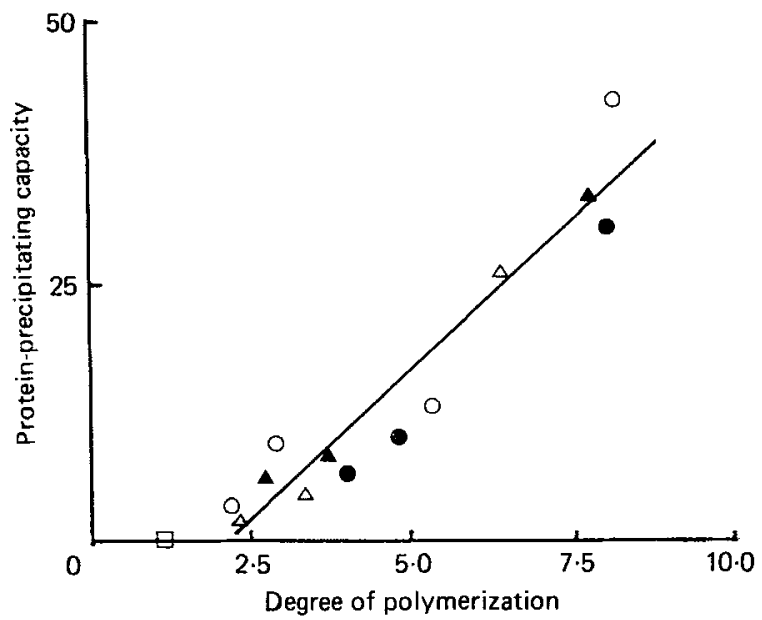

Fig. 1. Relation between the degree of polymerization and protein-precipitating capacity of tannins ( $r 0.855, P<0.01$ ). Protein-precipitating capacity was determined by measurement of the precipitated bovine serum albumin (BSA) in a mixture of each fractionated tannin $(5 \mathrm{mg})$, BSA (20 mg) and $0.067 \mathrm{M}$-phosphate buffer, $\mathrm{pH} 78$. (O), Black locust (Robinia pseudo-Acacia) tannins; (O), bush clover (Lespedeza bicolor) tannins; $(\triangle)$, wistaria (Wistaria floribunda) tannins; (A), Japanese knotgrass (Reynoutria japonica) tannins; ( $\square$ ), catechin. For experimental details, see pp. 277-278.

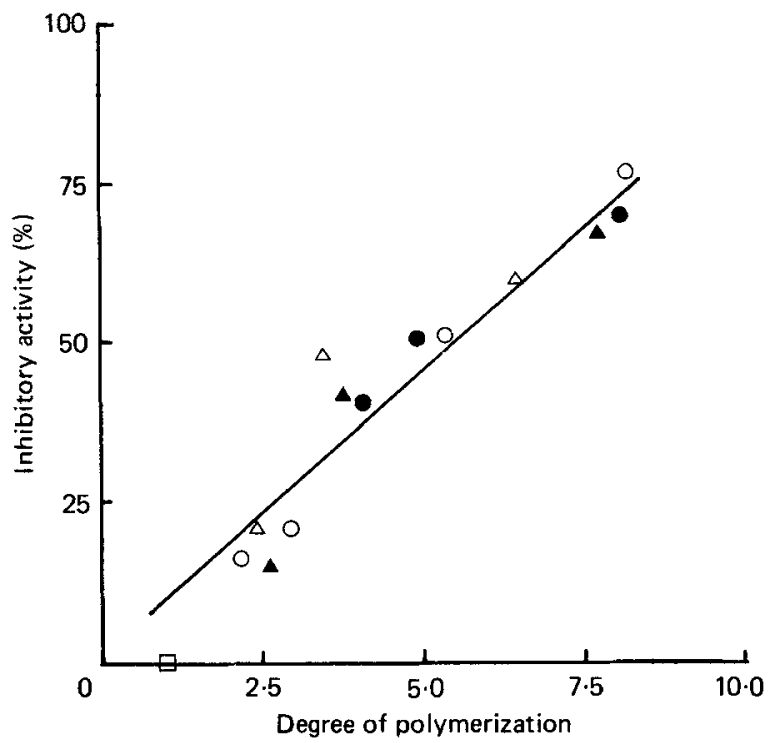

Fig. 2. Relation between the degree of polymerization and trypsin (EC 3 .4 .21 .4) inhibitor activity of tannins $(r 0.928, P<0.01)$. Inhibitory activity was calculated as the percentage of inhibition when the reduction in activity in the presence of each fractionated tannin was compared with the activity of trypsin in the absence of any tannin. (O), Black locust (Robinia pseudo-Acacia) tannins; (O), bush clover (Lespedeza bicolor) tannins; $(\triangle)$, wistaria (Wistaria floribunda) tannins; $(\mathbf{\Delta})$, Japanese knotgrass (Reynoutria japonica) tannins; $(\square)$, catechin. For experimental details, see pp. 276-277. 


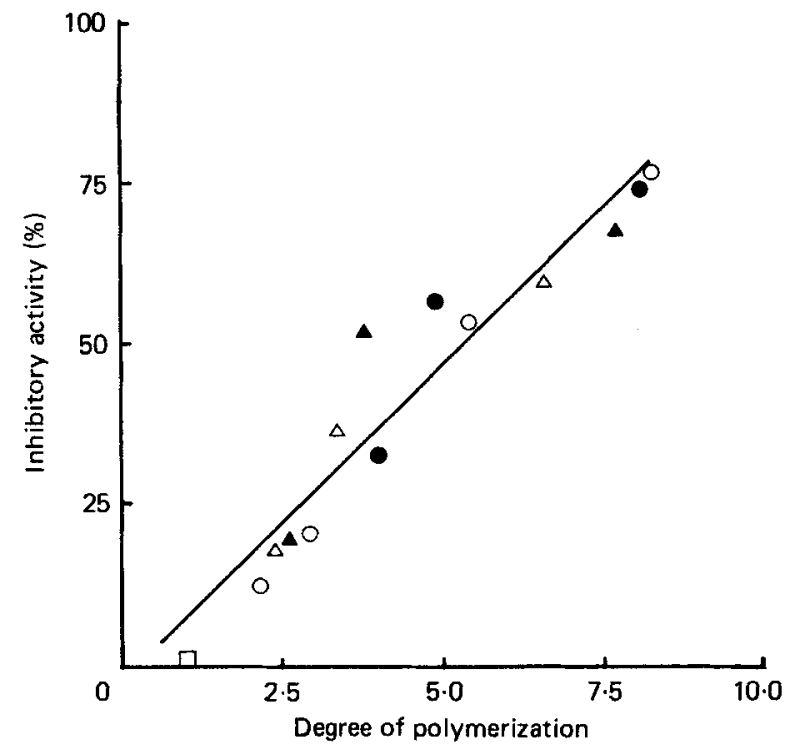

Fig. 3. Relation between the degree of polymerization and $\alpha$-amylase $(E C 3.2 .1 .1)$ inhibitor activity of tannins $(r 0.939, P<0.01)$. Inhibitory activity was calculated as the percentage of inhibition when the reduction in activity in the presence of each fractionated tannin was compared with the activity of $\alpha$ amylase in the absence of any tannin. (O), Black locust (Robinia pseudo-Acacia) tannins; $(O)$, bush clover (Lespedeza bicolor) tannins; $(\triangle)$, wistaria (Wistaria floribunda) tannins; $(\Delta)$, Japanese knotgrass (Reynoutria japonica) tannins; $(\square)$, catechin. For experimental details, see pp. 276-277.

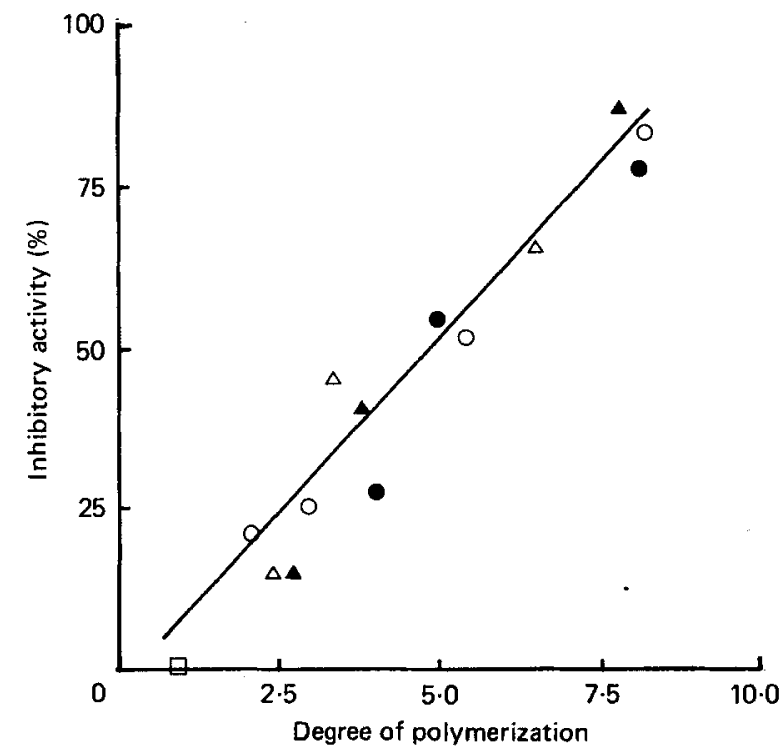

Fig. 4. Relation between the degree of polymerization and lipase (EC 3.1.1.3) inhibitor activity of tannins $(r 0.945, P<0.01)$. Inhibitory activity was calculated as the percentage of inhibition when the reduction in activity in the presence of each fractionated tannin was compared with the activity of lipase in the absence of any tannin. (O), Black locust (Robinia pseudo-Acacia) tannins; $(\mathcal{O})$, bush clover (Lespedeza bicolor) tannins; $(\triangle)$, wistaria (Wistaria floribunda) tannins; $(\mathbf{\Delta})$, Japanese knotgrass (Reynoutria japonica) tannins; ( $\square$ ), catechin. For experimental details, see pp. 276-277. 


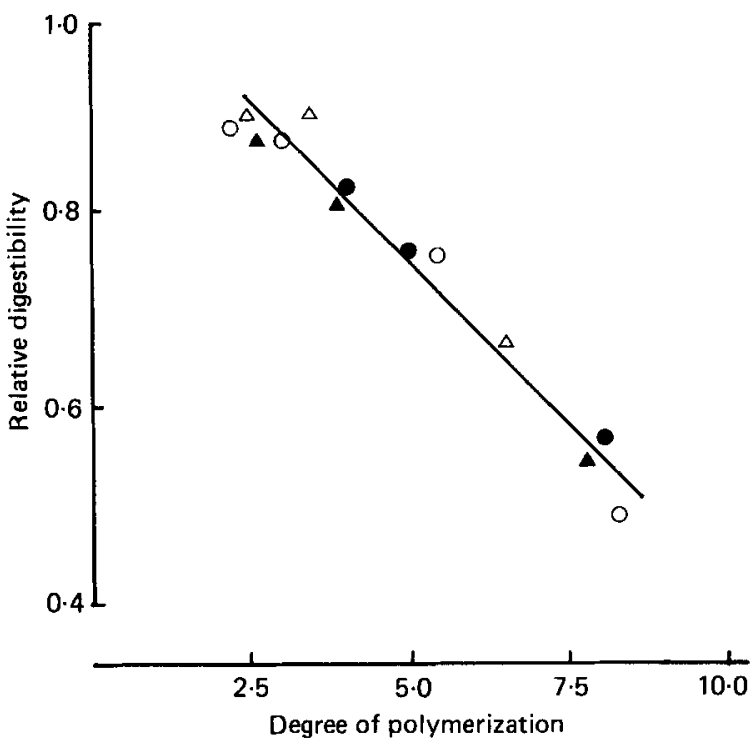

Fig. 5. Relation between the degree of polymerization of tannins and trypsin $(E C 3,4.21 .4)$ digestion of a tannin-protein complex $(r-0.972, P<0.01)$. The mixture of each fractionated tannin $(5 \mathrm{mg})$, bovine serum albumin $(20 \mathrm{mg})$ and $0.067 \mathrm{M}$-phosphate buffer, $\mathrm{pH} 7.8$, was kept at $37^{\circ}$. After $30 \mathrm{~min}$, trypsin $(0.25)$ was added to the reaction mixture. Relative digestibility was calculated on the basis of 1 for that in the absence of any tannin. (O), Black locust (Robinia pseudo-Acacia) tannins; (O), bush clover (Lespedeza bicolor) tannins; $(\triangle)$, wistaria (Wistaria floribunda) tannins; ( $\mathbf{\Lambda})$, Japanese knotgrass (Reynoutria japonica) tannins. For experimental details, see p. 277.

activity of the enzymes in each case was positively and linearly related to the degree of polymerization of tannins. Correlation coefficients for trypsin, $\alpha$-amylase and lipase were $0.928,0.939$ and 0.945 respectively.

Fig. 5 shows that when BSA was pre-incubated with tannins, trypsin digestion of BSA was inversely related to the degree of polymerization of tannins and the relation was also statistically significant $(r-0.972, P<0.01)$.

Influence of tannin administration on the digestive enzymes in the intestine of rats The trypsin, $\alpha$-amylase and lipase activities of the intestinal contents of rats fed on the basal and test diets are given in Table 2. The results show that the activities of trypsin and $\alpha$ amylase in each segment of the intestine were significantly depressed in rats fed on the test diet containing tannin $(10 \mathrm{~g} / \mathrm{kg})$, compared with those fed on the basal diet. Lipase activity in the upper and lower segments of the intestine was not influenced by the administration of tannin, while the activity of the middle segment was significantly enhanced.

\section{Digestion experiments with rats}

The results of digestion experiments are presented in Table 3. The digestibility of ADF was depressed in the antibiotic-treated rats compared with conventional rats, which suggests a reduction in microflora levels in the alimentary canal and the suppression of microbial digestion of nutrients by dietary antibiotic treatment (Eggum et al. 1979). Therefore, the digestion of nutrients in the alimentary canal of the antibiotic-treated rats may be attributable to the function of digestive enzymes. In the rats with reduced microflora levels, the administration of tannin $(20 \mathrm{~g} / \mathrm{kg}$ diet $)$ depressed the digestibilities of proximate constituents except crude fat (Table 3 ). In addition, as shown in Table 4, the levels of bile 
Table 2. Effect of tannins in the diet $\dagger$ on the activities (units $\ddagger$ ) of digestive enzymes in the small intestine of rats

(Mean values and standard deviations for three rats)

\begin{tabular}{|c|c|c|c|c|c|c|c|}
\hline & \multirow{3}{*}{$\begin{array}{l}\text { Tannins } \\
\text { in diet }\end{array}$} & \multicolumn{6}{|c|}{ Segment of intestine } \\
\hline & & \multicolumn{2}{|c|}{ Upper } & \multicolumn{2}{|c|}{ Middle } & \multicolumn{2}{|c|}{ Lower } \\
\hline & & Mean & SD & Mean & SD & Mean & SD \\
\hline Trypsin $(E C 3.4 .21 .4)$ & + & $\begin{array}{l}5 \cdot 3 \\
2 \cdot 0^{* *}\end{array}$ & $\begin{array}{l}0.6 \\
0.5\end{array}$ & $\begin{array}{l}15 \cdot 7 \\
7 \cdot 8^{* *}\end{array}$ & $\begin{array}{l}2 \cdot 1 \\
1 \cdot 1\end{array}$ & $\begin{array}{l}17 \cdot 0 \\
13 \cdot 4^{* *}\end{array}$ & $\begin{array}{l}2 \cdot 1 \\
0 \cdot 6\end{array}$ \\
\hline$\alpha$-Amylase $(E C$ 3.2.1.1) & $\overline{-}$ & $\begin{array}{l}11 \cdot 9 \\
4 \cdot 5^{* *}\end{array}$ & $\begin{array}{l}0.9 \\
0.4\end{array}$ & $\begin{array}{l}17 \cdot 2 \\
14 \cdot 2 * *\end{array}$ & $\begin{array}{l}1 \cdot 4 \\
1 \cdot 2\end{array}$ & $\begin{array}{l}22 \cdot 8 \\
16 \cdot 6^{* *}\end{array}$ & $\begin{array}{l}3 \cdot 8 \\
1.0\end{array}$ \\
\hline Lipase $(E C 3.1 .1 .3)$ & $\bar{t}$ & $\begin{array}{l}24 \cdot 7 \\
21 \cdot 4\end{array}$ & $\begin{array}{l}3 \cdot 0 \\
4.0\end{array}$ & $\begin{array}{l}39 \cdot 0 \\
47 \cdot 4^{* *}\end{array}$ & $\begin{array}{l}2 \cdot 8 \\
4 \cdot 8\end{array}$ & $\begin{array}{l}39.2 \\
38.8\end{array}$ & $\begin{array}{l}9 \cdot 3 \\
6.2\end{array}$ \\
\hline
\end{tabular}

-, Absent; +, present.

Mean values were significantly different from those for the rats without tannins: ${ }^{* *} P<0 \cdot 01$.

$\uparrow$ For details of diets, see p. 277.

$\ddagger$ For details, see p. 277.

Table 3. Effect of tannins in the diet $\dagger$ on the apparent digestibilities of dietary components (Mean values and standard deviations for four rats)

\begin{tabular}{|c|c|c|c|c|c|c|}
\hline \multirow[t]{3}{*}{ Microflora status $\ddagger \ldots$} & \multicolumn{2}{|c|}{ Normal } & \multicolumn{4}{|c|}{ Reduced } \\
\hline & \multirow[b]{2}{*}{ Mean } & \multirow[b]{2}{*}{ SD } & \multicolumn{2}{|c|}{ Tannins $(-)$} & \multicolumn{2}{|c|}{ Tannins (+) } \\
\hline & & & Mean & SD & Mean & SD \\
\hline Dry matter & 0.769 & 0.027 & 0.755 & 0.030 & $0 \cdot 683^{*}$ & 0.031 \\
\hline Crude protein (nitrogen $\times 6.25$ ) & 0.847 & 0.010 & 0.785 & 0.026 & $0.645^{* *}$ & 0.030 \\
\hline Crude fat & - & - & 0.814 & 0.017 & $0-833$ & 0.018 \\
\hline $\mathrm{ADF}$ & 0.242 & 0.024 & $0 \cdot 147$ & 0.032 & $0.072^{*}$ & 0.022 \\
\hline NFE & - & - & 0.758 & 0.034 & $0 \cdot 681^{*}$ & 0.040 \\
\hline
\end{tabular}

ADF, acid-detergent fibre; NFE, N-free extract; (-), absent; (+), present.

Mean values were significantly different from those of antibiotic-treated rats without tannins: ${ }^{*} P<0 \cdot 05$, $* * P<0.01$.

$\dagger$ For details of diets, see p. 277.

$\ddagger$ Microflora were reduced by a supply of $7 \mathrm{~g}$ antibiotics $/ \mathrm{kg}$ diet.

Table 4. Bile acids and crude protein (nitrogen $\times 6.25$ ) excreted in the faeces of rats fed on a diet containing tannins ${ }^{\dagger}$

(Mean values and standard deviations for four rats)

\begin{tabular}{lcccccc}
\hline \hline & \multicolumn{2}{c}{ Tannins (-) } & & \multicolumn{2}{c}{ Tannins (+) } \\
\cline { 2 - 3 } & Mean & SD & & Mean & SD \\
\hline Total faeces (g/d) & $2 \cdot 2$ & $0 \cdot 3$ & & $2 \cdot 8^{*}$ & $0 \cdot 3$ \\
Bile acids (mg/d) & $2 \cdot 6$ & $0 \cdot 4$ & & $5 \cdot 9^{* *}$ & $0 \cdot 1$ \\
Crude protein (mg/d) & 177 & 21 & & $290^{* *}$ & 22 \\
\hline
\end{tabular}

(-), Absent; (+), present.

Mean values were significantly different from those of rats without tannins: $* P<0.05, * * P<0 \cdot 01$

$\dagger$ Microflora in the alimentary canal were reduced by a supply of $7 \mathrm{~g}$ antibiotics $/ \mathrm{kg}$ diet. 
acids excreted in faeces of antibiotic-treated rats were enhanced by the administration of tannins.

\section{DISCUSSION}

All tannins isolated and fractionated from the leaves of black locust, bush clover, wistaria and Japanese knotgrass formed anthocyanidin pigments when they were heated in $\mathrm{HCl}-$ butanol solution and had an astringency and protein-precipitating ability which are typical and unique characteristics of condensed tannins. In addition, fractionated tannins ranged in their degree of polymerization from oligomer to octamer (Fig. 1). On the basis of these observations it may be concluded that these tannins are condensed tannins of proanthocyanidin type.

The protein-precipitating capacity of fractionated tannins using BSA increased with increasing degree of polymerization, in agreement with a previous report (Kumar \& Horigome, 1986), while catechin, a monomer, did not cause the precipitation of BSA from the buffer solution (Fig. 1). In addition, trypsin digestion of the BSA-tannin complex was inversely related to the degree of polymerization of the tannins (Fig. 5). Finally a negative correlation was found between the BSA-precipitating capacity of tannins and trypsin digestion of the BSA-tannin complex $(r-0.926, P<0.01)$. Therefore, the formation of an insoluble BSA-tannin complex appears to be a principal factor in the decrease in trypsin digestion of BSA when BSA was pre-incubated with tannins. It is widely accepted that condensed tannins react with various enzymes rendering them inactive. For example, tannins cause the precipitation of $\beta$-glucosidase $(E C 3.2 .1 .21)$ from solution by forming a tannin-enzyme complex and the enzyme activity is decreased (Goldstein \& Swain, 1965). Haslam (1974) suggested that the inhibition of $\beta$-glucosidase was due to the precipitation, not to inhibition of the enzyme by residual soluble phenols. Bate-Smith (1973) reported that the astringency of tannins, that is their efficiency as precipitants of proteins, increased progressively from low-molecular weight to high-molecular weight. McLeod (1974) stated in a review that the molecular size or molecular weight determined the reactivity of a tannin. Our present results support these reports. Figs. 2-4 show that the activity of tannins to inhibit trypsin, $\alpha$-amylase and lipase were dependent on the degree of polymerization. Thus although all enzymes were not subjected to the determination of protein-precipitating capacity, it seems reasonable to assume that the loss of enzyme activity observed in the present experiments is also principally due to the formation of an insoluble enzyme-tannin complex.

Although trypsin, $\alpha$-amylase and lipase were all inhibited by tannins in the in vitro experiment, the activity of lipase in the intestinal contents was not lowered or enhanced by the administration of tannins (Table 2). The digestibility of crude fat also was not affected by the administration of tannins in antibiotic-treated rats, while the digestibilities of crude protein $(\mathrm{N} \times 6.25)$ and dry matter were significantly lowered (Table 3$)$. Griffiths \& Moseley (1980) reported results comparable to our findings, that is, a significant increase in lipase activity in the intestinal contents of rats consuming diets containing field beans ( Vicia faba) of high tannin content in contrast to the reduction in trypsin and $\alpha$-amylase activities. Tamir \& Alumot (1969) found that carob (Ceratonia siliqua) tannins inhibited trypsin to a greater extent than did the glucoside of $m$-digallic acid (hydrolysable tannin), while the opposite was observed with lipase, and that $\alpha$-amylase was inhibited to the same extent by carob tannin and $m$-digallic acid. Their findings and our results indicate that the affinity of condensed tannins for lipase may be less than that for trypsin and $\alpha$-amylase, particularly under in vivo conditions.

The presence of tannins in the intestine of antibiotic-treated rats caused an increase in the excretion of bile acids and $N$ in faeces (Table 4). Sklan (1980) and Roy \& Schneeman 
(1981) suggested that undigested protein binds bile acids and impairs their absorption in the small intestine of chicks or mice. Our results are consistent with their findings and it can be assumed that bile acid absorption from the intestine was inhibited by binding to an undigested tannin protein complex and hence the levels of bile acids excreted were increased by the administration of tannins. Further work, however, is necessary to determine whether or not this is also the case for conventional rats.

\section{REFERENCES}

Barry, T. N. (1985). British Journal of Nutrition 54, 211-217.

Bate-Smith, E. C. (1973). Phytochemistry 12, 907-912.

Bernfeld, P. (1955). In Methods of Enzymology, pp. 149-150 [S. B. Colwick and N. O. Kaplan, editors]. New York: Academic Press.

Butler, L. G., Price, M. L. \& Brotherton, J. E. (1982). Journal of Agricultural and Food Chemistry 30, 1087-1089.

Chang, S. I. \& Fuller, H. L. (1964). Poultry Science 43, 30-36.

Eggum, O. B., Fekadu, M., Wolstrup, J., Sauer, W. C. \& Just, A. (1979). Journal of the Science and Food and Agriculture 30, 177-184.

Erlanger, B. F., Kokowsky, N. \& Choen, W. (1961). Archives of Biochemistry and Biophysics 95, 271-278.

Ford, J. E. \& Hewitt, D. (1979). British Journal of Nutrition 42, 325-340.

Goering, H. K. \& Van Soest, P. J. (1970). Agricultural Handbook no. 379. Washington, DC: United States Department of Agriculture.

Goldstein, J. L. \& Swain, T. (1965). Phytochemistry 4, 185-192.

Griffiths, D. W. \& Moseley, G. (1980). Journal of the Science of Food and Agriculture 31, 255-259.

Harper, A. E. (1959). Journal of Nutrition 68, 405-424.

Haslam, E. (1974). Biochemical Journal 139, 285-288.

Jones, W. T., Broadhurst, R. B. \& Lyttleton, J. W. (1976). Phytochemistry 15, 1407-1409.

Kalek, H. D., Stellaard, F., Kruis, W. \& Paumgartner, G. (1984). Clinica Chimica Acta 140, 85-90.

Kumar, R. \& Horigome, T. (1986). Journal of Agricultural and Food Chemistry 34, 487-489.

McLeod, M. N. (1974). Nutrition Abstracts and Reviews 44, 803 815.

Marquardt, R. R., Ward, A. T., Campbell, L. D. \& Cansfield, P. E. (1977). Journal of Nutrition 107, $1313-1324$.

Maxson, E. D., Rooney, L. W., Lewis, R. W., Clark, L. E. \& Johnson, J. W. (1973). Nutrition Reports International 8, 145-152.

Phillips, P. H. \& Hart, E. B. (1935). Journal of Biological Chemistry 109, 657-663.

Rostagno, H. S., Featherston, W. R. \& Rogler, J. C. (1973). Poultry Science 52, 765-772.

Roy, D. M. \& Schneeman, B. O. (1981). Journal of Nutrition 111, 878-885.

Seligman, A. M. \& Nachlas, M. M. (1963). In Methods in Enzymatic Analysis, 776-778 [H. U. Bergmeyer, editor]. New York: Verlag Chemie.

Sklan, D. (1980). Journal of Nutrition 110, 989-994.

Tamir, M. \& Alumot, E. (1969). Journal of the Science of Food and Agriculture 20, 199-202. 